\title{
Potyphyllum, a new phillipsastreid genus of rugose corals in the Upper Frasnian of Belgium with precisions about the age of the Petit-Mont Member
}

\author{
MARIE COEN-AUBERT
}

OD Earth and Life History, Institut royal des Sciences naturelles de Belgique, rue Vautier 29, B-1000 Bruxelles, Belgium; Marie.CoenAubert@naturalsciences.be.

ABSTRACT. The new genus Potyphyllum is erected with Cyathophyllum ananas Goldfuss, 1826 as type species, for which a neotype is selected here from the north side of the Namur Basin. It is a massive pseudocerioid rugose coral like Frechastraea Scrutton, 1968 with rather large corallites, spindle-shaped dilated septa as well as some horseshoe and inner dissepiments. In the Belgian Upper Frasnian, Potyphyllum ananas and P. veserense (Coen-Aubert, 1974) occur mainly in the Upper Palmatolepis rhenana conodont Zone. The latter two coral taxa, together with diverse species of Frechastraea and Phillipsastrea D'Orbigny, 1849, permit dating of the red marble lenses from the Petit-Mont Member which are developed at different levels of the Champ Broquet Formation, in the Dinant Synclinorium. In this lithostratigraphic unit are also incorporated the Neuville and Les Valisettes Members, formerly considered as two separate formations. At the present time, Potyphyllum is only known from Western and Eastern Europe.

KEYWORDS: Rugosa, taxonomy, lithostratigraphy, biostratigraphy, Frasnian

\section{Introduction}

This work serves as conclusion for the revision of massive rugose corals belonging to the family Phillipsastreidae Roemer, 1883 and occurring in the Upper Frasnian of Belgium. The diverse species of Frechastraea Scrutton, 1968 have been investigated in detail by Coen-Aubert $(2012,2015)$. As for Phillipsastrea D'Orbigny, 1849 , P. falsa Coen-Aubert, 1987 and P. ranciae Coen-Aubert, 1987 were described by Coen-Aubert (1987) and P. conili Tsien, 1978 was studied by Coen-Aubert (1994). The present paper is concerned with two pseudocerioid species like Frechastraea, but with larger corallites, which have been previously ascribed to Phillipsastrea, but which are herein assigned to the new genus Potyphyllum based on Cyathophyllum ananas Goldfuss, 1826 as type species. Most Belgian occurrences of Potyphyllum ananas and $P$. veserense (Coen-Aubert, 1974) characterize the Upper Palmatolepis rhenana conodont Zone. As mentioned by Coen-Aubert (2012, 2015), the base of the Upper Frasnian has been fixed by the Subcommission on Devonian Stratigraphy, at the entry of the conodont Palmatolepis semichatovae. In Belgium, the entry of $P$. semichatovae is observed within the Lower Palmatolepis rhenana Zone, together with the first occurrence of Ancyrognathus triangularis whereas the massive rugose coral Frechastraea coeni Coen-Aubert, 2012 can be considered as an excellent marker for the base of the Upper Frasnian. As it is explained by Coen-Aubert (2015), the expression Namur Basin is used in this paper instead of the term Namur Synclinorium.

The main part of the material investigated herein was collected by the author and Michel Coen in situ, during geological surveys made bed by bed in different localities from the southern part of Belgium (Fig. 1). This sampling is supplemented by a few older thin sections referred in this paper to the "Old collection from the Institut royal des Sciences naturelles de Belgique".

\section{Geological and stratigraphical setting}

Within the Dinant Synclinorium, the Champ Broquet Formation was proposed by Coen-Aubert (2015) to include the red marble lenses of the Petit-Mont Member as well as the Neuville and Les Valisettes Members which were formerly considered as two different formations. The stratotype of the Champ Broquet Formation in the Philippeville Massif is constituted by the northern and southern

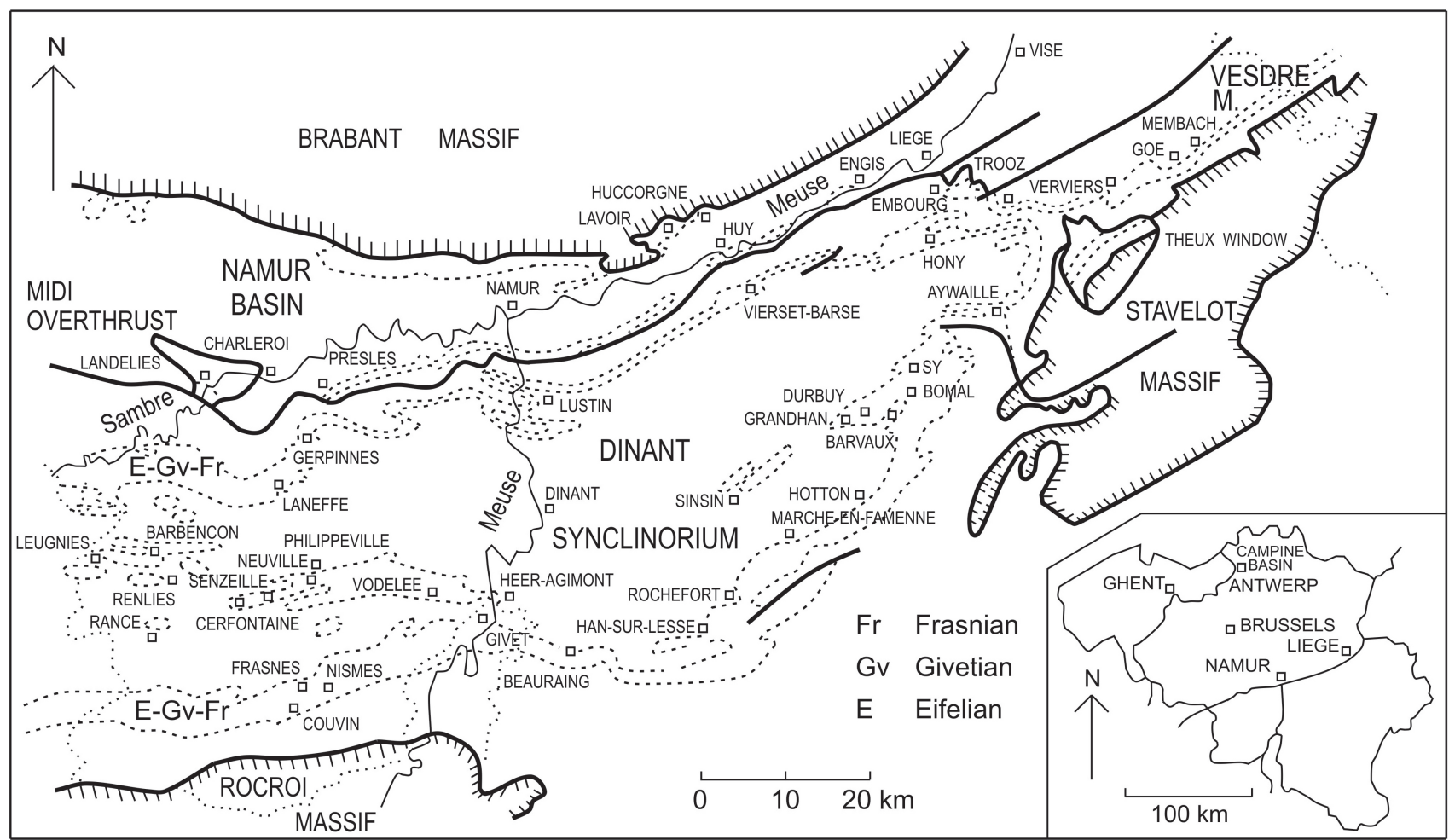

Figure 1. Geological setting and locality map in the southern part of Belgium. 
Figure 2. Schematic logs of the southern and northern railway sections of Neuville, which constitute the stratotype of the Champ Broquet Formation, with the nearby Les Bulants quarry and the distribution of rugose corals.

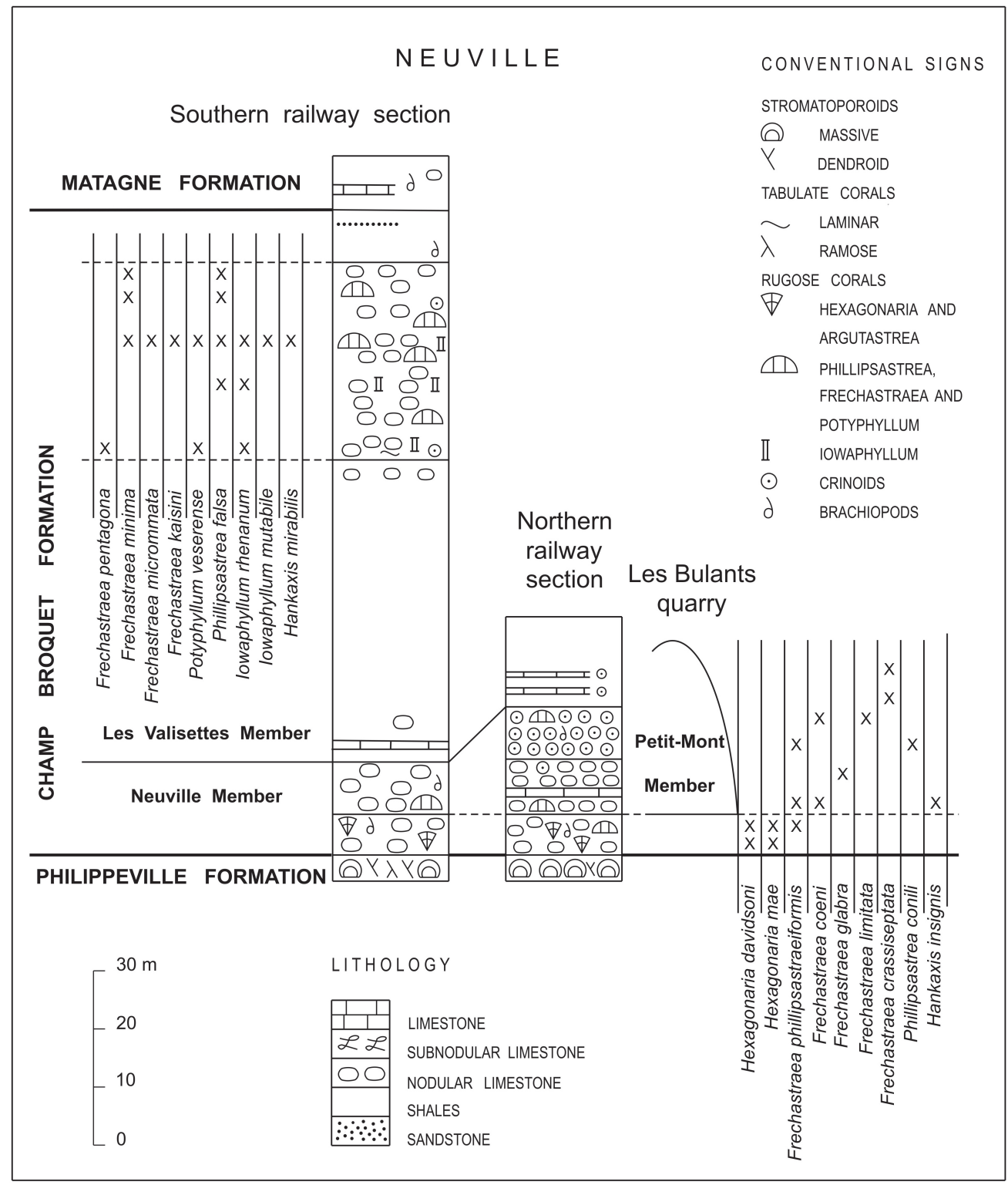

railway sections of Neuville described by Boulvain et al. (1999) and illustrated herein with the distribution of the rugose corals (Fig. 2). Laterally to the northern railway section of Neuville, the bioherm of the Petit-Mont Member is exposed in Les Bulants quarry. It is about $30 \mathrm{~m}$ thick and its base lies above the first $7 \mathrm{~m}$ of the Neuville Member which contain Hexagonaria davidsoni (MilneEdwards \& Haime, 1851), H. mae Tsien, 1978 and Frechastraea phillipsastraeiformis (Moenke, 1954). In fact, the bioherm starts at the level of nodular limestones rich in F. coeni and Ancyrognathus triangularis indicating the base of the Upper Frasnian. In the red lens of Les Bulants quarry occur also Frechastraea glabra CoenAubert, 2012, F. phillipsastraeiformis, F. limitata (Milne-Edwards \& Haime,1851) and the rare species Phillipsastrea conili whereas Frechastraea crassiseptata (Tsien, 1978) formerly identified as $F$. micrastraea (Penecke, 1904) by Coen-Aubert (2012) is observed in the last $10 \mathrm{~m}$. The same situation is reported in the Petit-Mont quarry at Vodelée which is the stratotype of the Petit-Mont Member. However, this reefal lens has a thickness of more than $70 \mathrm{~m}$ so that it is partly developed laterally to the Les Valisettes Member. $F$. crassiseptata has also been collected in its upper part together with Potyphyllum ananas. As mentioned by Coen et al. (1977, p. 329), this fauna is associated in both Les Bulants and Petit-Mont quarries with the conodont Ancyrognathus asymmetricus indicating the Upper Palmatolepis rhenana Zone. Frechastraea crassiseptata and Potyphyllum ananas also characterize the main part of the Petit-Mont Member excavated in the Haumont quarry at Vodelée; however, another fauna with $P$. veserense, Frechastraea pentagona (Goldfuss, 1826) and F. minima (Różkowska, 1953) appears at its top as noted by Boulvain et al. (2011, p. 38). These species with
Phillipsastrea falsa and Iowaphyllum rhenanum (Schlüter, 1880) are typical of the nodular limestones occurring in the upper part of the Les Valisettes Member from the south railway section of Neuville (Fig. 2). They have also been recorded in a few metres of the same facies at Cerfontaine and Philippeville and in the upper part of the lateral deposits to the Petit-Mont Member from Beauchâteau quarry at Senzeille which have been figured by Coen et al. (1977, fig. 3) and Birenheide et al. (1991, fig. 18). In a faulted outcrop of La Redoute at Cerfontaine studied by Mottequin (2004, p. 36), Potyphyllum ananas has been collected in a bed of coarsely crinoidal limestone just below the nodular and coralliferous limestones of the Les Valisettes Member. This bioclastic bed recalls the slope deposits exposed laterally or directly above the bioherms of the Petit-Mont Member in the Petit-Mont quarry at Vodelée, the Beauchâteau quarry at Senzeille (lower part of the lateral deposits) and the Tapoumont quarry at Neuville where $P$. ananas and Frechastraea crassiseptata are still recognized; the Tapoumont quarry has been investigated by Boulvain et al. (1988).

So the lenses of the Petit-Mont Member from the Philippeville Massif start in the Neuville Member, which constitutes their basement, and grow up more or less high in the Les Valisettes Member. In other parts of the Dinant Synclinorium, the position of the bioherms of the Petit-Mont Member may be very different. On the south side of this structural unit, these bioherms are often restricted to the Neuville Member and overlain by a great thickness of black shales belonging to the Matagne Formation whereas the Les Valisettes Member is poorly represented (Fig. 3). On the southeastern side of the Dinant Synclinorium, the red marble lenses of Sy, Bomal, Durbuy, Barvaux and Grandhan mentioned by Coen 
(1974) are entirely developed in the Les Valisettes Member and capped by purple shales of the Barvaux Formation. The massive rugose corals of this area are not as diversified as those of the Philippeville Massif (Fig. 4). Indeed, Hexagonaria davidsoni and H. mae have been found at the base of the Neuville Member in the sections of Durbuy and Le Rote to the south of Bomal described by Coen (1974, pp. 86 and 93). Frechastraea crassiseptata, F. limitata and Potyphyllum ananas are common in the lenses of the Petit-Mont Member from Sy, Durbuy, Bomal, Barvaux and Grandhan whereas $P$. veserense and Frechastraea pentagona have been observed locally in the Barvaux Formation at Sinsin and Marche-en-Famenne.

To the northwest of the Philippeville Massif, there are also small lenses of the Petit-Mont Member limited to the Les Valisettes Member. This is the case for the localities of Barbençon, SolreSaint-Géry and Leugnies studied by Dumoulin (2001, p. 24); in these bioherms occur F. crassiseptata and Potyphyllum ananas. A composite log for Barbençon is figured herein (Fig. 5) with some unpublished data of M. Coen. The lower part of the Neuville Member crops out in the Cuvelier quarry located by Dumoulin (2001, fig. 3). Hexagonaria davidsoni has been collected $2 \mathrm{~m}$ above the base of this lithostratigraphic unit. One meter higher, there are numerous specimens of Hankaxis insignis Coen-Aubert, 1982 and Frechastraea coeni with a few colonies of $F$. limitata. The conodont Ancyrognathus asymmetricus has been identified $23 \mathrm{~m}$ above the base of the Neuville Member, in the basement of a red bioherm which is about $20 \mathrm{~m}$ thick. These Upper Frasnian deposits of Barbençon are compared with those of Laneffe and Chastrès lying on the north side of the Dinant Synclinorium where there are no lenses of the Petit-Mont Member. The exposures of Laneffe and Chastrès (Fig. 5) have been investigated by Dumoulin \& Marion (1997, p. 26) and Boulvain et al. (1999, p. 81). The Neuville Member consists of $10 \mathrm{~m}$ of nodular limestones rich in Frechastraea coeni with rare specimens of $F$. phillipsastraeiformis; at the top of the member, Ancyrognathus triangularis is succeeded by A. asymmetricus. The Les Valisettes Member starts with $6.5 \mathrm{~m}$ of fine shales followed by $31.5 \mathrm{~m}$ of shales with several levels of carbonate nodules containing a few massive rugose corals represented by Frechastraea crassiseptata at their base, Potyphyllum ananas in their middle part and $P$. veserense at their top. The section ends with about $27 \mathrm{~m}$ of shales which are locally purple and show coquina beds in their upper part and still Ancyrognathus asymmetricus close to their top. According to Dumoulin (2001) and Dumoulin \& Marion (1997),
Figure 3. Lithostratigraphy in the Upper Frasnian of Belgium with the distribution of massive rugose corals on the north side of the Dinant Synclinorium, the south side of the Namur Basin and the Vesdre Massif. The broken line corresponds to the base of the Upper Frasnian.

Figure 4. Stratigraphic distribution of massive rugose in the Upper Frasnian from the Philippeville Massif and the southeastern side of the Dinant Synclinorium. The broken line corresponds to the base of the Upper Frasnian.

\begin{tabular}{|c|c|c|c|c|c|}
\hline $\begin{array}{l}\text { CONODONT } \\
\text { ZONES }\end{array}$ & $\begin{array}{l}\text { SOUTH SIDE OF THE } \\
\text { DINANT } \\
\text { SYNCLINORIUM }\end{array}$ & $\begin{array}{l}\text { SOUTHEASTERN } \\
\text { SIDE OF THE DINANT } \\
\text { SYNCLINORIUM }\end{array}$ & \multicolumn{3}{|c|}{$\begin{array}{c}\text { NORTH SIDE OF THE DINANT } \\
\text { SYNCLINORIUM, SOUTH SIDE OF } \\
\text { THE NAMUR BASIN, VESDRE MASSIF }\end{array}$} \\
\hline linguiformis & MATAGNF & $\begin{array}{l}\text { BARVAUX } \\
\text { FORMATION }\end{array}$ & \multicolumn{2}{|c|}{$\begin{array}{l}\text { LAMBERMONT } \\
\text { OR FALISOLLE } \\
\text { FORMATION }\end{array}$} & $\begin{array}{lll}1 & 1\end{array}$ \\
\hline Upper rhenana & FORMATION & $\begin{array}{c}\text { Les Valisettes } \\
\text { Member } \\
\text { CHAMP }\end{array}$ & \multirow{2}{*}{ 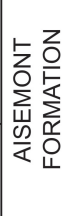 } & Upper Limestone & \multirow{2}{*}{ I I } \\
\hline & $\left.\begin{array}{c}\text { Petit-Mont } \\
\text { Member }\end{array}\right)$ Neuville & Member & & Lower Limestone & \\
\hline Lower rhenana & \multicolumn{2}{|c|}{ ORMAT } & \multirow{5}{*}{\multicolumn{2}{|c|}{ FORMATION }} & \multirow{6}{*}{ 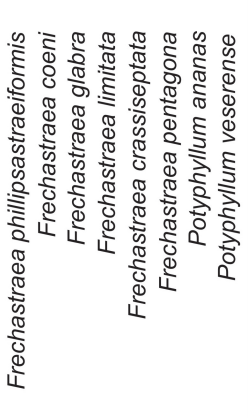 } \\
\hline jamieae & & & & & \\
\hline hassi & $\begin{array}{l}\text { GRANDS BREUX } \\
\text { FORMATION }\end{array}$ & $\begin{array}{l}\text { PHILIPPEVILLE } \\
\text { FORMATION }\end{array}$ & & & \\
\hline punctata & $\begin{array}{l}\text { MOULIN LIENAUX } \\
\text { FORMATION }\end{array}$ & $\begin{array}{c}\text { PONT DE LA FOLLE } \\
\text { FORMATION }\end{array}$ & & & \\
\hline transitans & & & & & \\
\hline falsiovalis & NISMES & FORMATION & NISM & $\begin{array}{l}\text { ES OR PRESLES } \\
\text { ORMATION }\end{array}$ & \\
\hline
\end{tabular}

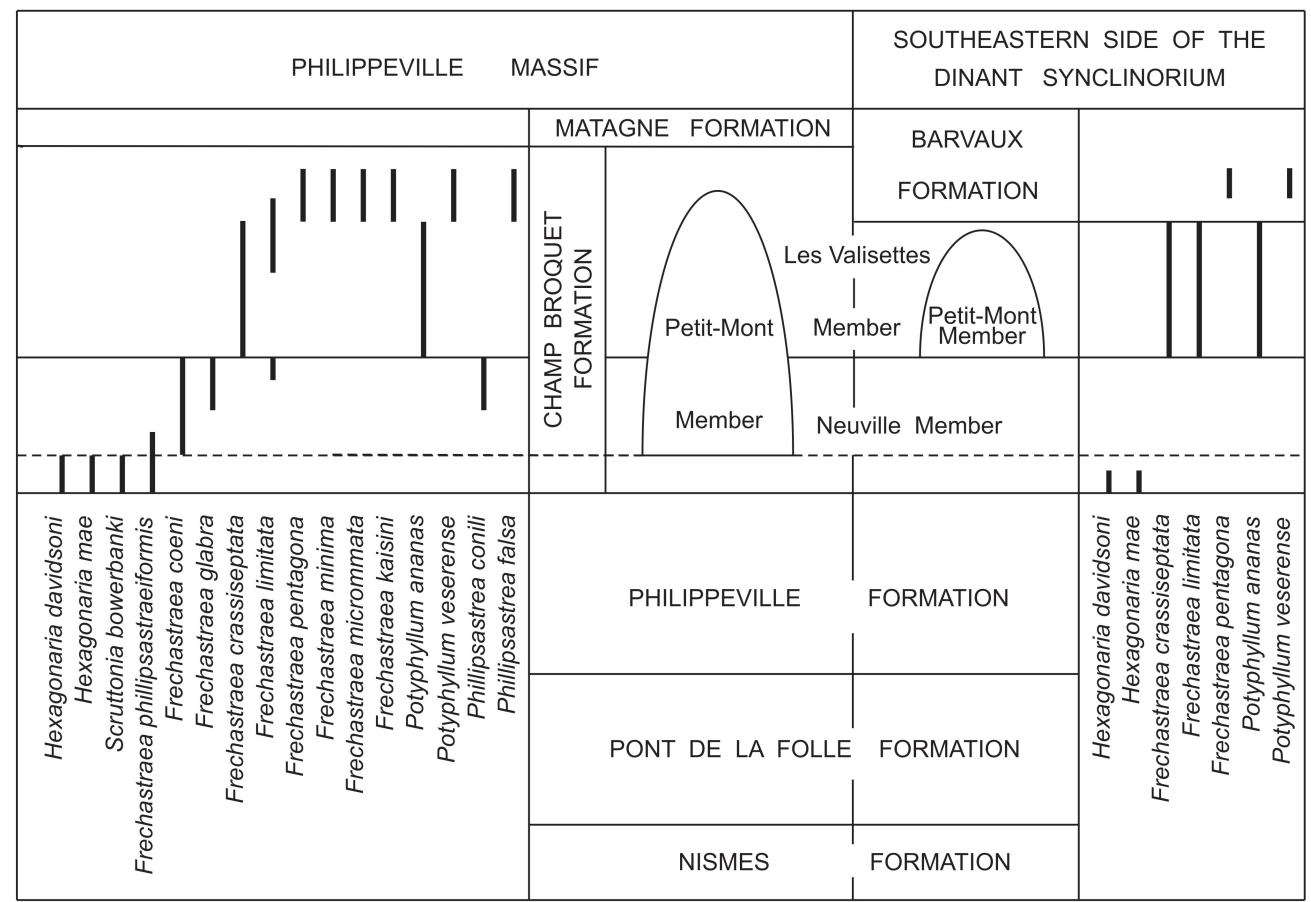


Figure 5. Composite comparative logs of Barbençon and the area of Laneffe and Chastrès with the distribution of rugose corals. The $\log$ of Barbençon is drawn after Dumoulin (2001, fig. 5b) whereas the $\log$ of Laneffe and Chastrès is drawn after the description given in Boulvain et al. (1999, p. 81). Unpublished data of M. Coen are also used. (For explanation of conventional signs, see Fig. 2).

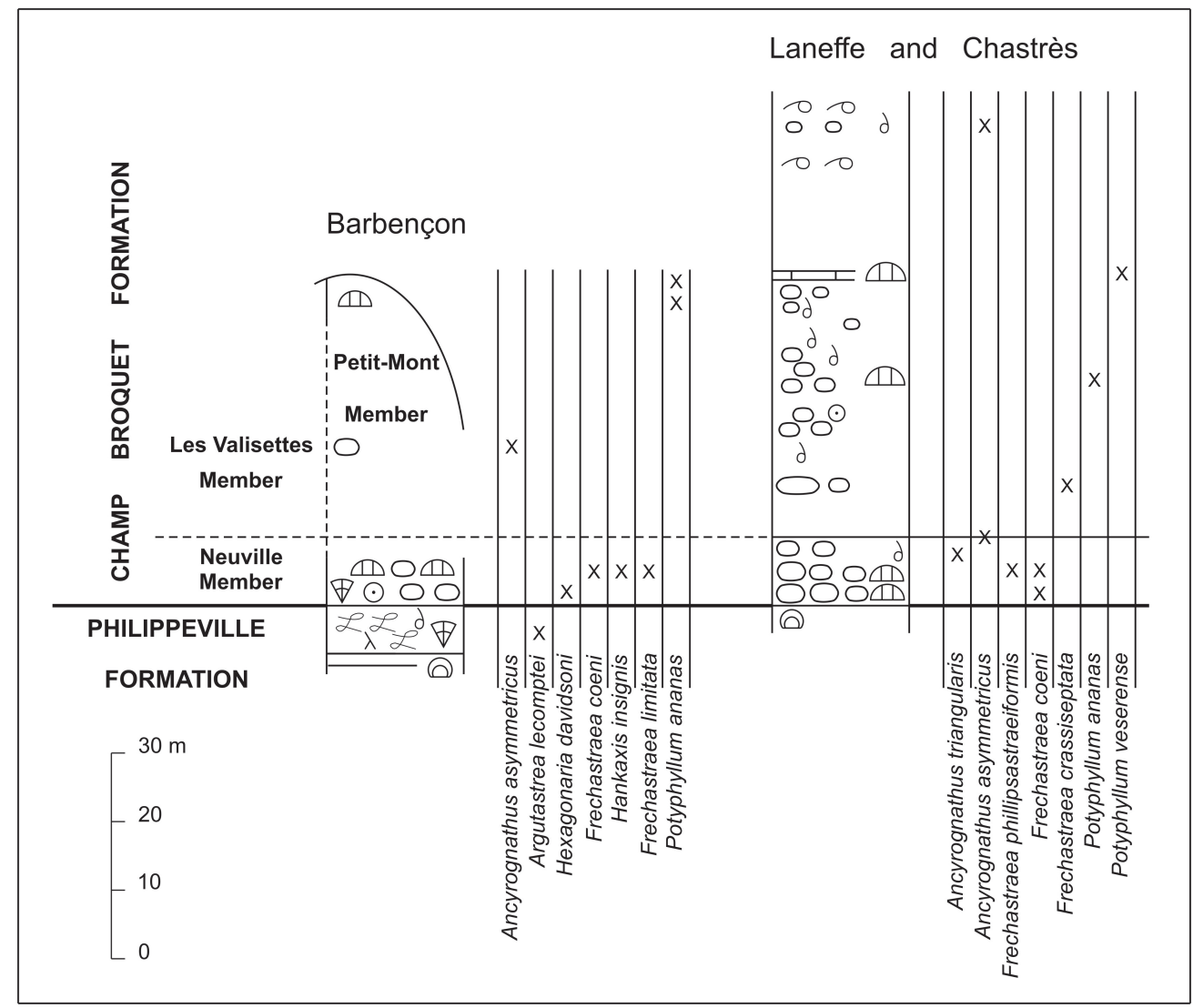

the Champ Broquet Formation is directly overlain by the Famenne Formation in this northwestern part of the Dinant Synclinorium. A similar situation has been recognized in the Renlies and Rance Anticlines to the south of Barbençon. After the data given by Biron et al. (1983) and Coen-Aubert (1987), Famennian conodonts of the Palmatolepis triangularis Zone have been identified in the Famenne Formation at Rance, just above a red lens of the Petit-Mont Member characterized by the occurrence of Frechastraea minima and Phillipsastrea ranciae. In the quarry Le Fief at Renlies located by Marion \& Barchy (2004, p. 20), P. falsa and Frechastraea pentagona have been sampled by M. Coen at the top of a red bioherm lying once more high in the Upper Frasnian.

In the northern areas, that is to say, at Huccorgne and Lavoir on the north side of the Namur Basin, on the south side of the same structural unit, in the Vesdre Massif and on the north side of the Dinant Synclinorium to the east of the Meuse valley, the Upper Frasnian is represented by the well known Aisemont and Lambermont Formations; the distribution of their massive rugose corals reillustrated herein (Fig. 3) has already been discussed by Coen-Aubert (2012, 2015). According to Coen (1974), the basement of the Petit-Mont Member between Grandhan and Sy, which corresponds to the base of the Matagne Formation on the south side of the Dinant Synclinorium, can be correlated with a bed of limestone from the middle shaly part of the Aisemont Formation at Comblainla-Tour and Aywaille, on its northeastern side. Additionally, the base of the Lambermont Formation is laterally equivalent to the base of the Barvaux Formation according to Boulvain et al. (1999, p. 62).

\section{Systematic Palaeontology}

The neotype of Potyphyllum ananas and all the figured specimens are stored in the Collection of Palaeontology from the Institut royal des Sciences naturelles de Belgique at Brussels (IRScNB).

Family Phillipsastreidae Roemer, 1883

\section{Genus Potyphyllum gen. nov.}

= Pseudoacervularia sensu Różkowska, 1953, non Schlüter, 1881.

Type species. Cyathophyllum ananas Goldfuss, 1826.
Derivation of name. The genus is dedicated to Edouard Poty, a distinguished Belgian specialist of Tournaisian and Viséan rugose corals who is also much interested in the investigation of the Belgian Upper Frasnian.

Diagnosis. Massive pseudocerioid rugose corals with rather large corallites. Septa of two orders, non-carinate or slightly carinate, spindle-shaped dilated in the inner part of the dissepimentarium. Major septa reaching the axis of the corallites or leaving an open space in the centre of the tabularium. Minor septa traversing the entire dissepimentarium. Dissepimentarium composed of several rows of globose dissepiments arranged in horizontal layers; some horseshoe dissepiments occurring close to the border of the tabularium and separated from it by inner inclined dissepiments. Narrow symmetrical fans of septal trabeculae centred over the horseshoe dissepiments. Tabulae incomplete or compound.

Discussion. The genus Potyphyllum is introduced herein for massive pseudocerioid rugose corals akin to Phillipsastrea which have been informally assigned to "Pseudoacervularia" by Rohart \& Semenoff-Tian-Chansky (1981, pp. 12, 18), Sorauf \& Pedder (1986, p. 1286) and McLean (1989, p. 240). It corresponds to the Phillipsastrea ananas species group of Wrzołek (2011, p. 193) and to Pseudoacervularia Schlüter, 1881 sensu Różkowska (1953, p. 49). Acervularia coronata Milne-Edwards \& Haime, 1851 from the Upper Givetian of South Devon in Great Britain was selected by Lang et al. (1940) as type species of Pseudoacervularia and is conspecific according to Scrutton (1968, p. 214) and McLean (1994, p. 53) with Phillipsastrea hennahi (Lonsdale, 1840) of the same age and area and type species of Phillipsastrea. So the two genera Phillipsastrea and Pseudoacervularia are synonyms. Różkowska (1953) invalidly chose Acervularia macrommata Roemer, 1855 as genotype for Pseudoacervularia. Though this species is inadequately known, it is considered by several authors to be conspecific with Potyphyllum ananas which is widely distributed in the Upper Frasnian of Belgium and for which a neotype is designated in this paper, not too far from the type area of Namur mentioned by Goldfuss (1826).

Phillipsastrea hennahi, type species of Phillipsastrea, has been investigated in detail by Scrutton (1968) in the Upper Givetian from South Devon in Great Britain. Phillipsastrea differs from Potyphyllum by astreoid to thamnasterioid colonies with variably developed horseshoe dissepiments and separated from the 
tabularium by rather few inner dissepiments. Diverse species of Phillipsastrea from the Givetian of Spain, Morocco and Mauritania showing these features have been described by Coen-Aubert (2013). Frechastraea is pseudocerioid as Potyphyllum, but it is characterized by much smaller corallites so that it is often possible to distinguish the two genera on the field, in the Upper Frasnian of Belgium. In Frechastraea also, the septa are uniformly dilated throughout the dissepimentarium and the horseshoe dissepiments are rather rare. $F$. pentagona from the Upper Frasnian of the Vesdre Massif in Belgium and type species of Frechastraea has been revised recently by Coen-Aubert (2015).

Potyphyllum is characterized by a straight or zigzagged pseudotheca with locally a dark median line. The same situation occurs in Smithicyathus Różkowska, 1979. In typical Upper Frasnian species of this taxon such as its type species $S$. cinctus (Smith, 1945) from the Northwest Territories in Canada, S. savagei Pedder, 2006 from Southeastern Alaska in USA and S. lubliniensis Różkowska, 1979 from the Lublin area in Poland, the corallum is partly aphroid whereas the septa are reduced or poorly developed in the outer dissepimentarium and separated from the corallite wall by large dissepiments. In other species such as $S$. lacunosus (Gürich, 1896) and S. smithi (Różkowska, 1953) from the Upper Frasnian of the Holy Cross Mountains in Poland and revised by Wrzołek (2007), the septa are nearly continuous throughout the dissepimentarium, restricted to it and strongly dilated in its inner part with a continuous pipe of horseshoe dissepiments at the border of the tabularium. All these features separate S. lacunosus and S. smithi from Potyphyllum. The material assigned to Pseudoacervularia cf. smithi by Pickett (1967, p. 52) is clearly pseudocerioid and is probably a species of Potyphyllum with rather small corallites and major septa reaching the axis of the corallites. It was considered by Wrzołek (2007, pp. 614, 622) to be close to Phillipsastrea ranciae from the Upper Frasnian of the Rance Anticline. However, the latter taxon is astreoid and is characterized by septa more thickened only at the border of the tabularium, by often complete tabulae and by much smaller septal number and diameters of the tabularia and corallites.

As mentioned by Pickett (1967, p. 27) and Coen et al. (1977, p. 326), Potyphyllum ananas and other species of that genus were probably derived from Hexagonaria Gürich, 1896. Both genera have spindle-shaped dilated septa in the inner part of their broad dissepimentarium and major septa reaching the axis of the corallites. However, Hexagonaria is cerioid whereas Potyphyllum is pseudocerioid with outer globose dissepiments arranged in horizontal layers and separated from the inner inclined dissepiments by some horseshoe dissepiments. In Belgium, the last representatives of Hexagonaria are succeeded close to the base of the Champ Broquet Formation by several species of Frechastraea whereas Potyphyllum ananas appears higher in the lithostratigraphic unit (Fig. 4). So it is not possible to follow in Belgium the continuous evolution between Hexagonaria and Potyphyllum. The latter genus was certainly not derived from Frechastraea.

Species assigned to the genus. In addition to the type species of Cyathophyllum ananas from the Upper Frasnian of Belgium, the following taxa are assigned to Potyphyllum:

- Pseudoacervularia dybowskii Różkowska, 1953 from the Upper Frasnian of the Holy Cross Mountains in Poland;

- Pseudoacervularia intercellulosa (Phillips, 1841) sensu Pickett (1967) from the Lower Frasnian of the Harz Mountains in Germany;

- Schlüteria lyskovensis Ermakova, 1957 from the Upper Frasnian of the Russian Platform;

- Acervularia macrommata Roemer, 1855 from the Middle Frasnian of the Harz Mountains in Germany;

- Phillipsastrea plantana Różkowska, 1979 from the Middle to Upper Frasnian of the Holy Cross Mountains in Poland;

- Cyathophyllum profundum Michelin, 1845 from the Givetian or the Frasnian of the Boulonnais in France;

- Phillipsastrea rozkowskae Scrutton, 1968 from the Upper Frasnian of South Devon in Great Britain;

- Pseudoacervularia cf. smithi (Różkowska, 1953) sensu Pickett

(1967) from the Lower Frasnian of the Harz Mountains in Germany;

- Phillipsastrea ananas veserensis Coen-Aubert, 1974 from the

Upper Frasnian of Belgium;
- Phillipsastrea zerda Galle, 1992 in Hladil et al. (1992) from the Upper Frasnian of Moravia in the Czech Republic.

\section{Potyphyllum ananas (Goldfuss, 1826)}

(Plate 1A-F; Plate 2E-G)

* p. 1826 Cyathophyllum ananas nobis; Goldfuss: 60, pl. 19, fig. $4 \mathrm{~b}$ (non fig. 4a).

1851 Acervularia troscheli; Milne-Edwards \& Haime: 416.

1855 Acervularia macrommata n. sp.; Roemer: 33, pl. 6, fig. 22; p. 1885 Phillipsastrea ananas Goldfuss, sp.; Frech: 49, pl. 2, figs 1-3, 5a-b, pl. 3, figs $1-3,14$, pl. 8 , fig. 9 (non pl. 2, fig. 4, pl. 3 , fig. 5).

1948 Phillipsastraea ananas Goldf.; Dembinska-Różkowska: fig. 22.

v 1953 Pseudoacervularia ananas (Goldfuss); Różkowska: 52, pl. 7, figs 1-2.

v 1953 Pseudoacervularia macrommata (F.A. Roemer); Różkowska: 49, pl. 7, figs 5-7.

v 1953 Pseudoacervularia roemeri (Verneuil \& Haime); Różkowska: 53, pl. 7, figs 3-4;

non 1966 Phillipsastraea cf. ananas (Goldfuss); Mirouse: 393, pl. 14 , fig. 3.

1967 Pseudoacervularia macrommata (F.A. Roemer, 1855); Pickett: pl. 2, fig. 8.

1967 Phillipsastraea macrommata (F.A. Roemer); Sorauf: 33, figs 14, 2a-c.

1968 Phillipsastrea ananas (Goldfuss); Scrutton: 228, pl. 5, figs $1-4$.

non 1970 Phillipsastrea macrommata (Roemer, F.A., 1855); Brice: 275, pl. 17, figs 1a-b.

v 1974a Phillipsastrea ananas ananas (Goldfuss, G.A., 1826); Coen-Aubert: 19, pl. 3, figs 5-6.

v non 1974a Phillipsastrea $\mathrm{cf}$. ananas ananas (Goldfuss, G.A., 1826); Coen-Aubert: pl. 4, figs 1-2.

v p. 1974a Phillipsastrea macrommata (Roemer, F.A., 1855); Coen-Aubert: p. 23, pl. 5, fig. 1;

v 1974b Phillipsastrea ananas (Goldfuss); Coen-Aubert: pl. 3, fig. 1.

1975 Phillipsastrea ananas; Tsien: fig. 26g.

1975 Phillipsastrea macrommata; Tsien: fig. 26h.

1977 Phillipsastrea ananas; Tsien: fig. 7e.

1977 Phillipsastrea macrommata; Tsien: fig. 7f.

1978 Phillipsastrea ananas (Goldfuss, 1826); Tsien: 203, fig. 2, pl. 1, fig. 3 .

1978 Phillipsastrea macrommata (Roemer, 1855); Tsien: 203, fig. 3.

1978 Phillipsastrea ananas (Goldfuss 1826); Birenheide: 100, pl. 15, fig. 2;

1978 Hexagonaria macrommata (F.A. Roemer) sensu Pickett 1967; Birenheide: 97, pl. 13, fig. 4;

1980 Phillipsastrea ananas (Goldfuss, 1826); Oekentorp: 104, pl. 16, fig. 3.

non 1981 Marisastrum macrommata (Roemer, 1855); Tsyganko: 67, pl. 30, fig. 3 .

non 1982 Hexagonaria ananas (Goldfuss); Wu et al.: 120, pl. 1, fig. 2.

non 1997 Phillipsastraea macrommata (Roemer); Tsyganko et al.: 42, pl. 6, figs 1-2.

v 2003 Phillipsastrea ananas (Goldfuss, 1826); Fedorowski: 102, pl. 47 , fig. 3 .

v 2003 Phillipsastrea macrommata (Roemer, 1855); Fedorowski: 103, pl. 47, figs 1-2.

? 2005 Phillipsastrea macrommata (Roemer, 1855); Schröder: 87, pl. 12, fig. 5 .

Holotype. Specimen formerly stored in the Goldfuss collection from the Paläontologisches Institute of the University of Bonn in Germany. Transition limestone from the area of Namur (Frasnian?) in Belgium. This specimen was chosen as lectotype by Coen-Aubert (1974a, p. 20), but is in fact a holotype by monotypy. In any case, it is lost as mentioned by Scrutton (1968, p. 228) and this situation was confirmed to me during my visit at Bonn in April 2007. Pl. 19, fig. 4b in Goldfuss (1826) only in external shape. 
Neotype (designated herein). IRScNB a 12989 (= Plate 1A-C). Specimen Couthuin MC-1980-2-X77 collected by M. Coen-Aubert in 1980, in the upper limestone level of the Aisemont Formation.

Type locality and horizon. Locality 7 lying to the southeast of Lavoir, below the Walloon motorway, described and located by Coen-Aubert \& Lacroix (1985, fig. 4). Map sheet Couthuin 48/2, Lambert coordinates: $\mathrm{x}=204.4$ and $\mathrm{y}=137.025$, north side of the Namur Basin. Upper limestone level of the Aisemont Formation, Upper Frasnian.

Material. In addition to the 25 colonies cited by Coen-Aubert (1974a), 70 specimens with 125 thin sections. Personal sampling with that of M. Coen, E. Groessens and F. Tourneur: Couthuin MC1980-2-X77; Braives MC-1979-2-W48, W49, W50, W52, W58, W59, W60, W62, W64, W65, W69 and W70; Fontaine l'Evêque MC-1974-137-L8; Limbourg MC-1974-53-A48; Verviers MC1988-4-A670, A671, A675, A680, A683 and A687; Chênée MC1974-83-L3; Huy MC-1974-105-H25I; Naninne MC-174-115-R60; Hamoir MC-133-1. 8581; Hamoir MC-1974-111-984B and 984C; Hamoir MC-120-D844, D845, D847, D849, D854, D859 and D863; Grandhan MC-39-B714, B719, B726, B727 and B730; Walcourt MC-1976-6-749; Beaumont MC-1977-14-770A, 770B, 770C and 770D; Beaumont MC-134-795; Grandrieu MC-1975-11-T8 and 1. 14459; Senzeille MC-1984-1-T200; Senzeille MC-1974-15-N56, B4, B5, B15, B15A, B17, B19, B19A, B20bis, B31 and B32; Froidchapelle MC-75-C989, D104, D112, D113 and D114; Surice MC-1974-133-V18 and V26; Surice MC-1986-5-B27 and B30; Agimont MC-129-Heer 2 and 3.

Diagnosis. A species of Potyphyllum with 28 to 38 septa at tabularial diameters of $2.8 \mathrm{~mm}$ to $4.6 \mathrm{~mm}$. Septa typically dilated in a wide zone of the inner dissepimentarium. Major septa reaching the axis of the corallites. Occurrence of some horseshoe dissepiments outside several rows of inner dissepiments.

Description. The material consists of sheet-like, platy, nodular and sometimes tabular or massive colonies which are complete or fragmentary. Their height varies commonly between $1.5 \mathrm{~cm}$ and $8 \mathrm{~cm}$, but reaches occasionally $12 \mathrm{~cm}$ to $16 \mathrm{~cm}$. The largest piece has an area of $11 \mathrm{~cm} \times 16 \mathrm{~cm}$. On the upper surfaces of some samples, excavated calices bordered by flat peripheral platforms can be observed. The polygonal corallites are separated by a straight or zigzagged pseudotheca. In several specimens, the outer wall is locally characterized by a dark median line. Pericalicinal and rarely lateral or axial offsets occur in a few colonies.

The septa are rather slender or more or less thick at the periphery. They are typically dilated in the inner part of the dissepimentarium. This wide zone of inner thickening is sometimes stronger (Plate 2E), weaker or narrower. A few small knobbly, spinose and even yardarm carinae may be present outside and inside this spindle-shaped area. In some specimens, the fusiform dilation of the septa occurs in nearly all the dissepimentarium; this situation is more frequent in small colonies with small corallites. The septa become thin in the tabularium or slightly beyond their entry into it. They are rarely weakly thickened in the tabularium.

The major septa reach usually the axis of the corallites or leave occasionally a small open space in the centre of the tabularium which is more important in very few corallites. Their axial ends are rather often fusing laterally to form pseudofossulae and in rare cases a plane of bilateral symmetry. The minor septa traverse the entire dissepimentarium; sometimes they are somewhat shorter, discontinuous at their inner ends or barely projecting into the tabularium. Herringbone dissepiments may be present at the border of the tabularium.

The dissepimentarium consists of 3 to 11 rows of globose dissepiments which are arranged in horizontal layers at the periphery and inclined at its inner end. At the bases of some corallites, the dissepiments are restricted to 1 or 2 series whereas there are up to 14 to 17 series at maturity, in a few colonies from Cerfontaine. Horseshoe or specialized dissepiments occur rather often within the dissepimentarium and they are separated from the tabularium by 1 to 5 rows of inner dissepiments (Plate 1B-C, E-F). In three colonies, peneckielloid dissepiments have also been observed. Some symmetrical tight fans of septal trabeculae are centred over the horseshoe dissepiments. The tabulae are incomplete and intersecting laterally or compound with broad flat-topped axial parts.

There are 24 to 42 septa per corallite. The width of the tabularium ranges from $2.5 \mathrm{~mm}$ or even $2 \mathrm{~mm}$ to $5.7 \mathrm{~mm}$. The diameter of the corallites varies commonly between $5.5 \mathrm{~mm}$ and $12.5 \mathrm{~mm}$ and more generally between $4.7 \mathrm{~mm}$ or even $4.2 \mathrm{~mm}$ and $16 \mathrm{~mm}$.

Discussion. The abundant Belgian material of Potyphyllum ananas shows a wide variability mostly related to the size of the corallites. The main part of the colonies has large corallites and tabularia with about 28 to 38 septa. However, there are also some specimens with small corallites and tabularia and about 26 to 32 septa (Plate 2F-G) whose spindle-shaped dilation may be stronger, narrower or extending to nearly all the dissepimentarium. These colonies of smaller size occur mostly in the red bioherms of the PetitMont Member and they are accompanied by samples of $P$. ananas with larger corallites. These specimens with smaller corallites are more similar to those described as P. macrommatum by Różkowska (1953). However, it is clear that these particular Belgian specimens enter into the variability of $P$. ananas. Additionally, it is clear also that the colonies figured by Różkowska $(1953, \mathrm{pl} .7)$ as $P$. ananas, $P$. macrommatum and Phillipsastrea roemeri (De Verneuil \& Haime, 1850 ) belong to the same species. The type specimen of $P$. roemeri from the Harz Mountains in Germany, which is inadequately known, is probably conspecific with $P$. hennahi according to Scrutton (1968, p. 220). Potyphyllum ananas and P. macrommatum were considered as synonyms or close species by Frech (1885), Scrutton (1968), Birenheide (1978) and Schröder (2005). The original material of $P$. macrommatum has only been poorly illustrated by Roemer (1855) without thin sections and any longitudinal section.

Concerning the references excluded from the list of synonymy, the colonies from the Upper Givetian of the Pyrenees in France and from the Frasnian of Afghanistan described respectively by Mirouse (1966) and Brice (1970) have septa that are weakly carinate and thickened in the inner dissepimentarium. The septa of the specimen illustrated by Schröder (2005) are slightly spindle-shaped dilated in a narrow zone at the border of the tabularium. On the contrary, the Frasnian material investigated from Tibet in China by Wu et al. (1982) and from the Northern Urals and Southern Timan in Russia by Tsyganko (1981) and Tsyganko et al. (1997) is characterized by septa more or less thick across the whole dissepimentarium. As for the Belgian sample identified as $P$. cf. ananas by Coen-Aubert (1974a), it is locally cerioid with rather slender septa and may belong to Hexagonaria davidsoni.

Several taxa are closely related to Potyphyllum ananas. The holotype of P. zerda illustrated by Hladil et al. (1992, pl. 12, figs $1-2)$ is poorly preserved and has rather few septa. The German material assigned to Phillipsastrea intercellulosa by Pickett (1967, p. 51) and Birenheide (1978, p. 97) is different from Potyphyllum ananas in having septa strongly thickened in a wide zone of the dissepimentarium. The holotype of Phillipsastrea intercellulosa from the Givetian of South Devon in Great Britain has been figured by Scrutton (1968, pl. 2, figs 2-3) and is once more conspecific with P. hennahi. Potyphyllum lyskovense and $P$. dybowskii are represented by massive to phaceloid colonies which resemble $P$. ananas. $P$. lyskovense has been referred to Peneckiella Soshkina, 1939 by McLean (2005, p. 41) and is mainly separated from $P$. ananas by a more or less continuous row of horseshoe dissepiments bordered by rare inner dissepiments. $P$. dybowskii is characterized by the same feature and by fusiform septa in a rather narrow zone at the border of the tabularium. Phillipsastrea samsonowiczi (Różkowska, 1953) from the Upper Frasnian of the Holy Cross Mountains in Poland is more fasciculate than Potyphyllum dybowskii and the septa of its holotype figured by Różkowska (1953, pl. 6, figs 7-8) and ascribed by this author to Pseudoacervularia have nearly no inner thickening. According to Wrzołek (2007, p. 614), the two latter species are very similar, which is not my opinion.

Distribution. The species has been collected in situ by the author, M. Coen, E. Groessens and F. Tourneur, in different coral deposits from the Upper Frasnian of Belgium. On the north side of the Namur Basin, in the La Tombe, Streupas and Kinkempois outliers, the Vesdre Massif, the Theux Window as well as on the 
north and east sides of the Dinant Synclinorium, it is already present in the lower limestone level of the Aisemont Formation, but it is more abundant in the upper one; it occurs locally at the base of the overlying Lambermont Formation. At Laneffe, on the north side of the Dinant Synclinorium, one colony has been observed about $21 \mathrm{~m}$ above the base of the Les Valisettes Member (Fig. 5). Potyphyllum ananas is common in the red bioherms of the Petit-Mont Member from Barbençon, Solre-Saint-Géry and Leugnies, in the northwestern part of the Dinant Synclinorium and from Neuville, Senzeille, Vodelée and Heer-Agimont in the Philippeville Massif; at Cerfontaine, several specimens have been sampled just below the base of the nodular limestones from the Les Valisettes Member. The species is also widespread on the east side of the Dinant Synclinorium, in the red bioherms of Sy, Bomal, Durbuy, Barvaux and Grandhan.

Outside Belgium, P. ananas is known in the Upper Frasnian from South Devon in Great Britain and from the Holy Cross Mountains in Poland. It occurs also in the Frasnian of the Aachen Syncline and the Harz Mountains in Germany and may be present in the Upper Frasnian of the East Sauerland, in the same country.

\section{Potyphyllum veserense (Coen-Aubert, 1974)}

(Plate 1G-H; Plate 2A-D)

* v 1974a Phillipsastrea ananas veserensis n. subsp.; Coen-Aubert: 21, pl. 4, figs 3-6.

v p. 1974a Phillipsastrea macrommata (Roemer, F.A., 1855); CoenAubert: 23 (non pl. 5,fig. 1).

v 1974b Phillipsastraea sp.; Coen-Aubert: pl. 3, fig. 2.

Holotype. Specimen IRScNB a733 (= Verviers MC-1974-7-19) stored in the Collection of Palaeontology from the Institut royal des Sciences naturelles de Belgique at Brussels, Belgium. Locality 7 to the north of Pepinster in the Vesdre Massif, Belgium, which has been described by Coen-Aubert (1974b, p. 61). Lower part of the Lambermont Formation, Upper Frasnian. Pl. 4 fig. 3 in Coen-Aubert (1974a).

Material. 24 specimens with 45 thin sections. Personal sampling with that of M. Coen: Verviers MC-1974-7-19; Limbourg MC-19749-A88; Esneux MC-1974-89-D71 and F85; Walcourt MC-1976-5750 and 751; Grandrieu MC-1974-158-1181; Senzeille MC-1974139-697; Senzeille MC-1974-14-P32, P35 and P45; Froidchapelle MC-71-C945; Froidchapelle MC-75-C990 and C995; Surice MC1986-5-B47; Aye MC-114-D811, D813, D816, D818A, D819, D822 and D823. Old collection from the Institut royal des Sciences naturelles de Belgique : Esneux 5380 (close to Esneux MC-197489) - F2II-16616 and 16617.

Diagnosis. A species of Potyphyllum with 24 to 32 septa at tabularial diameters of $2.5 \mathrm{~mm}$ to $4 \mathrm{~mm}$. Septa rather slender at the periphery and only spindle-shaped dilated at the border of the tabularium. Major septa reaching the axis of the corallites. Horseshoe and inner dissepiments weakly developed.

Description. The material consists of sheet-like, platy and nodular colonies which are complete or fragmentary. Their height varies between $1.5 \mathrm{~cm}$ and $7 \mathrm{~cm}$ whereas the largest piece has an area of $18 \times 16 \mathrm{~cm}$. The corallites polygonal in shape are separated by a straight or zigzagged pseudotheca. Rare lateral offsets have been observed.

The septa are non-carinate or bear a few small carinae. The septa are slender or faintly dilated in the greater part of the dissepimentarium. Usually, they are weakly spindle-shaped thickened at the border of the tabularium and this situation concerns mostly the major septa. In a few colonies, this inner dilation is stronger or somewhat wider. The septa become thin in the tabularium or slightly beyond their entry into it.

The major septa reach commonly the axis of the corallites or leave occasionally a small open space in the centre of the tabularium which is more important in a few cases. Their axial ends are rather often fusing laterally to form pseudofossulae and sometimes a plane of bilateral symmetry. The minor septa traverse the entire dissepimentarium and rarely project into the tabularium. Occasionally, they do not extend to the inner border of the dissepimentarium where herringbone dissepiments may be observed; they are discontinuous in rare corallites.

The dissepimentarium consists of 5 to 13 or even 18 rows of globose dissepiments which are arranged in horizontal layers and only inclined at its inner end. In some colonies, horseshoe or specialized dissepiments occur locally at the border of the tabularium or separated from it by 1 or 2 rows on inner inclined dissepiments. The tabulae are incomplete and intersecting laterally with sometimes a flat-topped axial part; they are rarely horizontal or concave.

There are 24 to 36 septa per corallite. The width of the tabularium ranges from $2.3 \mathrm{~mm}$ to $4.4 \mathrm{~mm}$. The diameter of the corallites varies commonly between $7 \mathrm{~mm}$ and $12.5 \mathrm{~mm}$ and more generally between $6 \mathrm{~mm}$ and $16.5 \mathrm{~mm}$.

Discussion. Potyphyllum veserense differs from $P$. ananas by septa rather slender at the periphery and only spindle-shaped dilated at the border of the tabularium, by fewer inner dissepiments and by faintly smaller septal number and diameter of the tabularium for corallites of nearly the same size. The two specimens from Hony (Esneux MC-1974-89) were assigned by Coen-Aubert (1974a) to P. macrommatum because one of them shows a stronger thickening in the inner dissepimentarium. $P$. plantanum is separated from $P$. veserense by a weaker zigzagged pseudotheca, by the slight dilation of all the septa in the inner part of the dissepimentarium and by somewhat more septa and larger tabularia.

Phillipsastrea conili, a rare species occurring at the base of the Upper Frasnian in Belgium, has already been compared with Potyphyllum veserense by Coen-Aubert (1994, p. 37). It is astreoid with once more all the septa thickened at the border of the tabularium. It resembles more Phillipsastrea falsa which is characterized by fewer septa and by smaller tabularia and corallites. P. falsa is associated with Potyphyllum veserense in the Les Valisettes Member from the Philippeville Massif. However, it is easy to distinguish the two taxa by their quantitative data and their outer wall: typically pseudocerioid in P. veserense and astreoid in Phillipsastrea falsa. It must be added that the pseudocerioid colony from Beauchâteau quarry at Senzeille, ascribed by Tsien $(1978$, pl. 2, fig. 6) to $P$. conili, probably belongs to Potyphyllum veserense. There are also some affinities between the latter species and a specimen from the Frasnian of Stolberg in the Aachen Syncline, Germany, identified by Frech (1885, pl. 4, fig. 3$)$ as Phillipsastrea roemeri.

Distribution. Potyphyllum veserense is only known rather high in the Upper Frasnian of Belgium and Cousolre in France. The material collected by the author and M. Coen comes from:

- the lower part of the Lambermont Formation at Pepinster and Les Surdents in the Vesdre Massif and at Hony, on the north side of the Dinant Synclinorium;

- the Les Valisettes Member at Laneffe and Cousolre in the northwestern part of the same structural unit and in the Philippeville Massif, at Philippeville, Neuville and Cerfontaine whereas $P$. veserense has also been observed at the top of the Petit Mont Member in the Haumont quarry at Vodelée;

- the Barvaux Formation at Marche-en-Famenne, on the southeast side of the Dinant Synclinorium.

\section{Conclusions}

Although Potyphyllum veserense is only present in the Upper Frasnian of Belgium, P. ananas is also known in the Upper Frasnian from South Devon in Great Britain and from the Holy Cross Mountains in Poland; moreover, it occurs in the Frasnian from the Aachen Syncline, which is the continuation of the Vesdre Massif to the east, and from the Harz Mountains in Germany. A similar palaeogeographic distribution has been pointed out by Coen-Aubert (2015) for Frechastraea pentagona, F. minima, F. limitata and F. phillipsastraeiformis. Other species of Potyphyllum have been introduced in the same areas as well as in the Upper Frasnian from Moravia in the Czech Republic and from the Russian Platform; one taxon is from the Boulonnais in France. At the present time, Potyphyllum has only been recorded in Europe and can be considered as a good marker for the Frasnian of the Old Wold Realm. 
Another important conclusion of this work concerns the red lenses of the Petit-Mont Member which occupy a variable position in the Upper Frasnian Champ Broquet Formation of the Dinant Synclinorium. Though their lithofacies and microfacies are rather similar according to the detailed descriptions of diverse outcrops given among others by Boulvain $(1993,2001)$, their ages are very different as it can be deduced from the identification of conodonts and massive rugose corals (Figs 3-4). About the latter group of fossils, Frechastraea coeni is frequent in the lower limestone level of the Aisemont Formation, close to the base of the Neuville Member and in the lower part of the bioherms from the Petit-Mont Member in the Philippeville Massif. It is sometimes accompanied by F. glabra, F. phillipsastraeiformis, F. limitata and Phillipsastrea conili. Frechastraea crassiseptata, F. limitata and Potyphyllum ananas are the species characteristic of the upper limestone level from the Aisemont Formation; they occur also on the southeastern side of the Dinant Synclinorium, in the lenses of the Petit-Mont Member developed laterally to the Les Valisettes Member. $P$. ananas and Frechastraea crassiseptata are abundant in the upper part of the red bioherms from the Philippeville Massif. F. pentagona, Potyphyllum veserense and occasionally Iowaphyllum rhenanum are locally present in the lower part of the Lambermont Formation, in the Barvaux Formation and in the upper part of the Les Valisettes Member. In the Philippeville Massif, these taxa are associated with Phillipsastrea falsa and Frechastraea minima and rarely with $F$. micrommata (Roemer, 1852) and F. kaisini (Tsien, 1978). Some of these species are sometimes observed at the top of the Petit-Mont Member in the Philippeville Massif and the Renlies Anticline. At Rance, F. minima is accompanied by Phillipsastrea ranciae, just below Famennian shales dated by conodonts. To complete this overview of the Belgian Upper Frasnian, Potyphyllum ananas and Frechastraea limitata have been identified by Coen-Aubert (2014) in the upper limestone level of the Aisemont Formation intersected by the Booischot borehole in the Campine Basin whereas $F$. pentagona is present at the base of the overlying Falisolle Formation in the Heibaart borehole. Close to the top of the Frasnian from the Visé Massif, colonies of F. minima and Phillipsastrea falsa have been studied by Coen-Aubert $(1987,2015)$. This is rather strange as these two taxa are only known elsewhere in Belgium, from the Philippeville Massif.

From a biostratigraphic point of view, Frechastraea coeni is restricted to the Lower Palmatolepis rhenana conodont Zone whereas there are two associations of massive rugose corals within the Upper P. rhenana Zone: the lower one with Potyphyllum ananas and Frechastraea crassiseptata often associated with by F. limitata, the upper one with F. pentagona, Potyphyllum veserense and diverse species in the Philippeville Massif. Generally, these massive rugose corals do not reach the Upper Kellwasser Event and the FrasnianFamennian boundary. At Rance, there is an unconformity between the Petit-Mont Member and the Famennien shales of the Famenne Formation as indicated by Muchez et al. (1996). So it appears that the top of the bioherms from the Petit-Mont Member is variable in age.

\section{Acknowledgements}

Several specimens were collected by Michel Coen, Eric Groessens and Francis Tourneur. The thin sections were made by Arthur Nijs, René Cremers and by the Laboratory of Edouard Poty (Liège) whose technical assistance was provided to me for more than 20 years. Wilfried Miseur and Thierry Hubin helped me for the photographs of the corals. This paper contributes to IGCP 596 on Mid-Paleozoic climate and biodiversity. Anthony Wright and Julien Denayer reviewed very carefully the manuscript. I am most grateful to all these persons. However, I am only responsible for the opinions presented in this paper.

\section{References}

Birenheide, R., 1978. Rugose Korallen des Devon. In Krömmelbein, K. (ed.), Leitfossilien begründet von G. Gürich. 2, völlig neu bearbeitete Auflage, $n^{\circ}$ 2. Gebrüder Borntraeger, Berlin-Stuttgart, $265 \mathrm{p}$.

Birenheide, R., Coen-Aubert, M., Lütte, B.P. \& Tourneur, F., 1991. Excursion B1, Devonian coral bearing strata of the Eifel Hills and the Ardenne. In Lütte, B.P. (ed.), VI. International Symposium on Fossil Cnidaria including Archaeocyatha and Porifera, Excursion-
Guidebook. Forschungsstelle für Korallenpaläozoologie, Münster, $113 \mathrm{p}$.

Biron, J. P., Coen-Aubert, M., Dreesen, R., Ducarme, B., Groessens, E. \& Tourneur, F., 1983. Le Trou de Versailles ou Carrière à Roc de Rance. Bulletin de la Société belge de Géologie, 92, 317-336.

Boulvain, F., 1993. Sédimentologie et diagenèse des monticules micritiques « F2j » du Frasnien de l'Ardenne. Service Géologique de Belgique, Professional Papers, 1993/2 (260), 1-427.

Boulvain, F., 2001. Facies architecture and diagenesis of Belgian Late Frasnian carbonate mounds. Sedimentary Geology, 145, 269-294.

Boulvain, F., Bultynck, P., Coen, M., Coen-Aubert, M., Lacroix, D., Laloux, M., Casier, J.G., Dejonghe, L., Dumoulin, V., Ghysel, P., Godefroid, J., Helsen, S., Mouravieff, N.A., Sartenaer, P., Tourneur, F. \& Vanguestaine, M., 1999. Les formations du Frasnien de la Belgique. Memoirs of the Geological Survey of Belgium, 44, 1-125.

Boulvain, F., Coen-Aubert, M., Da Silva, A.C., Kershaw, S., Tourneur, F., Denayer, J., Mottequin, B. \& Poty, E., 2011. Field Trip 1: Givetian and Frasnian of Southern Belgium. In Aretz, M. \& Poty, E. (eds), 11th International Symposium on Fossil Cnidaria and Porifera, Liège, August, 19-29, 2011 - Fields Guides. Kölner Forum für Geologie und Paläontologie, 20, 5-49.

Boulvain, F., Coen-Aubert, M. \& Tourneur, F., 1988. Sédimentologie et Coraux du bioherme de marbre rouge frasnien ("F2j") de Tapoumont (Massif de Philippeville, Belgique). Annales de la Société Géologique de Belgique, 110, 225-240.

Brice, D., 1970. Etude paléontologique et stratigraphique du Dévonien de l'Afghanistan. Contribution à la connaissance des Brachiopodes et des Polypiers Rugueux. Notes et Mémoires sur le Moyen-Orient, $11,1-364$.

Coen, M., 1974. Le Frasnien de la bordure orientale du Bassin de Dinant. Annales de la Société Géologique de Belgique, 97, 67-103.

Coen, M., Coen-Aubert, M. \& Cornet, P., 1977. Distribution et extension stratigraphique des récifs à "Phillipsastrea" dans le Frasnien de 1'Ardenne. Annales de la Société Géologique du Nord, 96, 325-331.

Coen-Aubert, M., 1974a. Représentants des genres Phillipsastrea D’Orbigny, A., 1849, Billingsastraea Grabau, A.W., 1917 et Iowaphyllum Stumm, E.C., 1949 du Frasnien du Massif de la Vesdre et de la bordure orientale du Bassin de Dinant. Bulletin de l'Institut royal des Sciences naturelles de Belgique, Sciences de la Terre, 49/8, $1-38$.

Coen-Aubert, M., 1974b. Le Givetien et le Frasnien du Massif de la Vesdre. Stratigraphie et paléogéographie. Mémoires in quarto de la Classe des Sciences de 1'Académie Royale de Belgique, $2^{\mathrm{e}}$ série, 18/2, 1-146.

Coen-Aubert, M., 1982. Rugueux solitaires du Frasnien de la Belgique. Bulletin de l'Institut royal des Sciences naturelles de Belgique, Sciences de la Terre, 54/6, 1-65.

Coen-Aubert, M., 1987. Nouvelles sous-espèces de Phillipsastrea hennahi (Lonsdale, W., 1840) dans le Frasnien supérieur de la Belgique. Bulletin de l'Institut royal des Sciences naturelles de Belgique, Sciences de la Terre, 56, 45-55.

Coen-Aubert, M., 1994. Stratigraphie et systématique des Rugueux de la partie moyenne du Frasnien de Frasnes-lez-Couvin (Belgique). Bulletin de l'Institut royal des Sciences naturelles de Belgique, Sciences de la Terre, 64, 21-56.

Coen-Aubert, M., 2012. New species of Frechastraea Scrutton, 1968 at the base of the Late Frasnian in Belgium. In Denayer, J., Aretz, M. \& Poty, E. (eds). Proceedings of the 11th International Symposium on Fossil Cnidaria and Porifera, Liège, 2011. Geologica Belgica, 15, 265-272.

Coen-Aubert, M., 2013. Phillipsastreids and Ptenophyllids (Rugosa) from the Givetian of Mauritania and Northwestern Spain. Geologica Belgica, 16, 164-178.

Coen-Aubert, M., 2014. Revision of the Frasnian marine deposits from the Booischot borehole (Campine Basin, Belgium). Geologica Belgica, 17, 333-337.

Coen-Aubert, M., 2015. Revision of the genus Frechastraea Scrutton, 1968 (Rugosa) in the Upper Frasnian of Belgium. Geologica Belgica, 18/2-4, 109-125.

Coen-Aubert, M. \& Lacroix, D., 1985. Le Frasnien dans la partie orientale du bord nord du Synclinorium de Namur. Bulletin de la Société belge de Géologie, 94, 117-128.

Dembinska-Różkowska, M., 1948. Korale Dewonskie Gor Swietokrzyskich. Wiadomosci Muzeum Ziemi, 3: 187-220.

De Verneuil, E. \& Haime, J., 1850. Polypiers. In De Verneuil, E., Note sur les fossiles dévoniens du district de Sabero (Léon). Bulletin de la Société Géologique de France, $2^{\mathrm{e}}$ série, 7, 161-162.

D’Orbigny, A., 1849. Note sur des polypiers fossiles. Victor Masson, Paris, $12 \mathrm{p}$.

Dumoulin, V., 2001. Carte géologique de Wallonie : Grandrieu-Beaumont 52/5-6. 1/25.000. Namur, Ministère de la Région wallonne, Direction générale des ressources naturelles et de l'environnement, avec une notice explicative de $70 \mathrm{p}$. 
Dumoulin, V. \& Marion, J.M., 1997. Carte géologique de Wallonie Silenrieux-Walcourt 52/7-8. 1/ 25.000. Namur, Ministère de la Région wallonne, Direction générale des ressources naturelles et de l'environnement, avec une notice explicative de $75 \mathrm{p}$.

Ermakova, K.A., 1957. Novye vidy devonskikh korallov rugoza iz tsentralnykh oblastey Russkoy Platformy. Trudy Vsesoyuznyi Nauchno-Issledovatelskiy Geologo-Razvedochnyi Neftanoy Institut, 8, 160-191. [In Russian].

Fedorowski, J., 2003. Typ Coelenterata, Gromada Anthozoa Ehrenberg, 1834, Podgromady: Rugosa Milne Edwards \& Haime, 1850-Dividocorallia Fedorowski, 1991. In Malinowska, L. (ed.), Budowa Geologiczna Polski, tom 3, Atlas Skamienialosci przewodnich i charakterystycznych, czesc 1b-z.1, Dewon. Panstwowy Instytut Geologiczny, Warszawa, 49-124 and Atlas.

Frech, F., 1885. Die Korallenfauna des Oberdevons in Deutschland. Zeitschrift der Deutschen geologischen Gesellschaft, 37, 21-130.

Goldfuss, A., 1826. Petrefacta Germaniae 1, 1-76. Arnz \& Comp., Düsseldorf.

Gürich, G., 1896. Das Palaeozoicum im Polnischen Mittelgebirge. Verhandlungen der Russisch-kaiserlichen Mineralogischen Gesellschaft zu St. Petersburg, serie 2, 32, 1-539.

Hladil, J., Krejci, Z., Kalvoda, J., Ginter, M., Galle, A. \& Berouzek, P., 1992. Carbonate ramp environment of Kellwasser time-interval (Lesni Lom, Moravia, Czechoslovakia). Bulletin de la Société belge de Géologie, 100, 57-119.

Lang, W.D., Smith, S. \& Thomas, H.D., 1940. Index of Palaeozoic Coral genera. British Museum (Natural History), London, $231 \mathrm{p}$.

Lonsdale, W., 1840. In Sedgwick, A. \& Murchison, R.I., On the physical structure of Devonshire and on the subdivisions and geological relations of its older stratified deposits. Transactions of the Geological Society of London, series 2, 5, 697.

Marion, J.M. \& Barchy, L., 2004. Carte géologique de Wallonie : SivryRance 57/1-2. 1/ 25.000. Namur, Ministère de la Région wallonne, Direction générale des ressources naturelles et de l'environnement, avec une notice explicative de $50 \mathrm{p}$.

McLean, R.A., 1989. Phillipsastreidae (Rugosa) in the Frasnian of Western Canada. Memoirs of the Association of Australasian Palaeontologists, 8, 239-249.

McLean, R.A., 1994. Frasnian rugose corals of Western Canada. Part 3A: The massive Phillipsastreidae - Phillipsastrea, Chuanbeiphyllum. Palaeontographica, Abteilung A, 230, 39-76.

McLean, R.A., 2005. Phillipsastreid corals from the Frasnian (Upper Devonian) of Western Canada: Taxonomy and biostratigraphic significance. NRC Research Press, Ottawa, Ontario, 109 p.

Michelin, H., 1840-1847. Iconographie zoophytologique, description par localités et terrains des polypiers fossiles de France et pays environnants. P. Bertrand, Paris, 348 p. et Atlas (1845: 145-185).

Milne-Edwards, H. \& Haime, J., 1851. Monographie des Polypiers fossiles des terrains paléozoïques. Archives du Muséum d'Histoire Naturelle, 5, 1-502.

Mirouse, R., 1966. Recherches géologiques dans la partie occidentale de la zone primaire axiale des Pyrénées. Mémoires pour servir à l'explication de la carte géologique détaillée de la France, Imprimerie nationale, Paris, $451 \mathrm{p}$.

Moenke, M., 1954. Rodzaj Hexagonaria w dewonie Gor Swietokrzyskich. Acta Geologica Polonica, 4, 445-483.

Mottequin, B., 2004. The genus Iowatrypa Copper, 1973 (Brachiopoda) in the Les Valisettes Formation (late Frasnian of the Philippeville Anticlinorium, southern, Belgium). Bulletin de l'Institut royal des Sciences naturelles de Belgique, Sciences de la Terre, 74, 35-44.

Muchez, P., Boulvain, F., Dreesen, R. \& Hou, H.F., 1996. Sequence stratigraphy of the Frasnian-Famennian transitional strata: a comparison between South China and southern Belgium. Palaeogeography, Palaeoclimatology, Palaeoecology, 123, 289-296.

Oekentorp, K., 1980. Coelenterata. Fossilien Westfalens; Invertebraten des Oberdevons. Münstersche Forschungen zur Geologie und Paläontologie, 50, 85-126.

Pedder, A.E.H., 2006. Zoogeographic data from studies of Palaeozoic corals of the Alexander terrane, southeastern Alaska and British Columbia. Geological Association of Canada, Special Paper, 46, 2957.

Penecke, K.A., 1904. Das Sammelergebnis Dr. Franz Schaffer's aus dem Oberdevon von Hadschin im Antitaurus. Jahrbuch der KaiserlichKöniglichen Geologischen Reichsanstalt, 53, 141-152.

Phillips, J., 1841. Figures and descriptions of the Palaeozoic Fossils of Cornwall, Devon and West Somerset. Longman, Brown, Green \& Longmans, London, $231 \mathrm{p}$.

Pickett, J., 1967. Untersuchungen zur Familie Phillipsastreidae (Zoantharia rugosa). Senckenbergiana lethaea, 48, 1-89.

Roemer, C.F., 1852-1854. H.G. Bronn's Lethaea Geognostica, Erster Band, Theil 2, Kohlen-Periode (Silur-, Devon-, Kohlen- und Zechstein Formation). Stuttgart, 788 p. and Atlas.
Roemer, C.F., 1883. Lethaea geognostica. I. Theil, Lethaea palaeozoica. Zweite Lieferung. Stuttgart, 324-543 und Atlas.

Roemer, F.A., 1855. Beiträge zur geologischen Kenntniss des nordwestlichen Harzgebirges. Dritte Abtheilung. Palaeontographica, 5: $1-44$.

Rohart, J.C. \& Semenoff-Tian-Chansky, P., 1981. Description des types de Hexagonaria davidsoni (Milne-Edwards et Haime) et de "Pseudoacervularia" profunda (Michelin), Tétracoralliaires du Dévonien du Boulonnais. Bulletin du Muséum national d'Histoire naturelle, $4 \mathrm{e}$ série, 3 (section $\mathrm{C}, \mathrm{n}^{\circ} 1$ ), 3-29.

Różkowska, M., 1953. Pachyphyllinae et Phillipsastrea du Frasnien de Pologne. Palaeontologia Polonica, 5, 1-89.

Różkowska, M., 1979. Contribution to the Frasnian Tetracorals from Poland. Palaeontologia Polonica, 40, 3-56.

Schlüter, C., 1880. Über Zoantharia rugosa aus dem rheinischen Mittelund Ober-Devon. Sitzungs-Bericht der Gesellschaft naturforschender Freunde zu Berlin, 1880/3, 50-53.

Schlüter, C., 1881. Über einige Anthozoen des Devon. Zeitschrift der Deutschen Geologischen Gesellschaft, 33, 75-108.

Schröder, S., 2005. Stratigraphie und Systematik rugoser Korallen aus dem Givetium und Unter-Frasnium des Rheinischen Schiegergebirges (Sauerland/Bergisches Land). Zitteliana, B25, 39-116.

Scrutton, C.T., 1968. Colonial Phillipsastraeidae from the Devonian of South-East Devon, England. Bulletin of the British Museum (Natural History), Geology, 15/5, 181-281.

Smith, S., 1945. Upper Devonian Corals of the Mackenzie River region, Canada. Special Papers Geological Society of America, 59, 1-126.

Sorauf, J.E., 1967. Massive Devonian Rugosa of Belgium. The University of Kansas Paleontological Contributions, 16, 1-41.

Sorauf, J.E. \& Pedder, A.E.H., 1986. Late Devonian rugose corals and the Frasnian-Famennian crisis. Canadian Journal of Earth Sciences, $23,1265-1287$.

Soshkina, E.D., 1939. Verkhnedevonskie korally Rugosa Urala. Trudy Paleontologicheskogo Instituta, 9, 1-88. [In Russian].

Tsien, H.H., 1975. Introduction to the Devonian Reef development in Belgium. Livret-Guide, Excursion C (Nord de la France et de la Belgique), 2e Symposium International sur les Coraux et Récifs coralliens fossiles, Paris 1975. Bruxelles, 3-43.

Tsien, H.H., 1977. The sequence and distribution of Frasnian rugose corals fauna in Belgium. Mémoires du B.R.G.M., 89, 203-220.

Tsien, H.H., 1978. Rugosa massifs du Dévonien de la Belgique. Mémoires de l'Institut Géologique de l'Université de Louvain, 29, 197-229.

Tsyganko, V.S., 1981. Devonskie rugozy Severa Urala. Leningrad "Nauka", 220 p. [In Russian].

Tsygango, V.S., Bogoyavlenskaya, O.V. \& Lukin, V.Yu., 1997. Kishechnopolostnye iz otlozhenyi devona ochparminskogo vala (Yuzhnyi Timan, r. Vol). Trudy Instituta Geologii (Syktyvkarskiy paleontologicheskiy Sbornik 2), 91, 30-48. [In Russian].

Wrzołek, T., 2007. A revision of the Devonian rugosan phillipsastreid genus Smithicyathus. Acta Palaeontologica Polonica, 52, 609-632.

Wrzołek,T., 2011. Soft taxonomy - case of Devonian phillipsastreid rugose corals. In Aretz, M., Delculée, S., Denayer, J. \& Poty, E. (eds), $11^{\text {th }}$ International Symposium on Fossil Cnidaria and Porifera, Liège, August 19-29, 2011 - Abstracts. Kölner Forum für Geologie und Paläontologie, 19, 191-193.

Wu, W.S., Liao, W.H. \& Zhao, J.M., 1982. Palaeozoic rugose corals from Xizang. The Series of the Scientific Expedition to the QinghaiXizang Plateau, Palaeontology of Xizang, 4, 107-151.

Manuscript received 30.06.2015, accepted in revised form 23.10.2015, available on line 31.01.2016. 


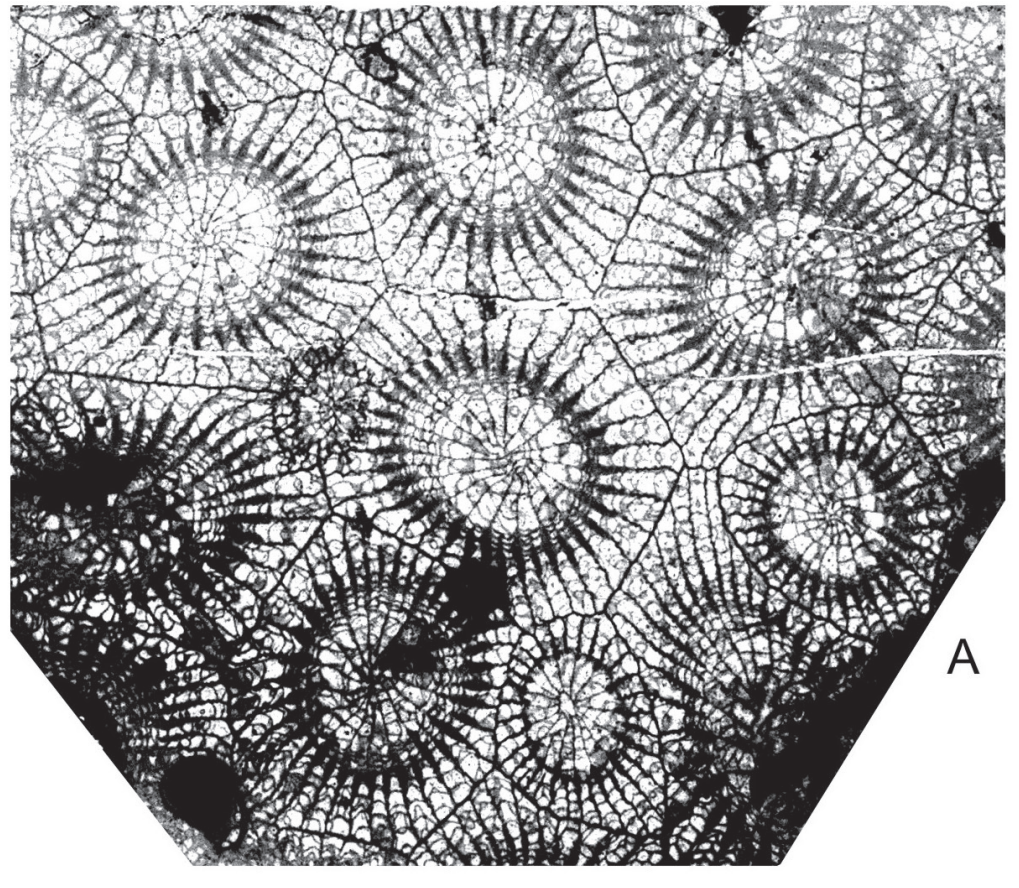

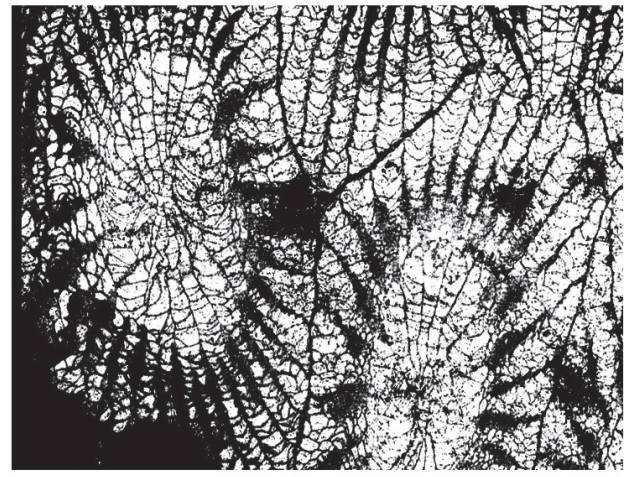

B

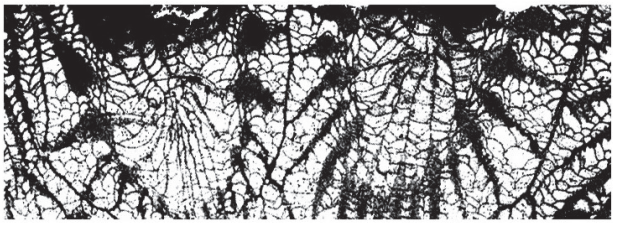

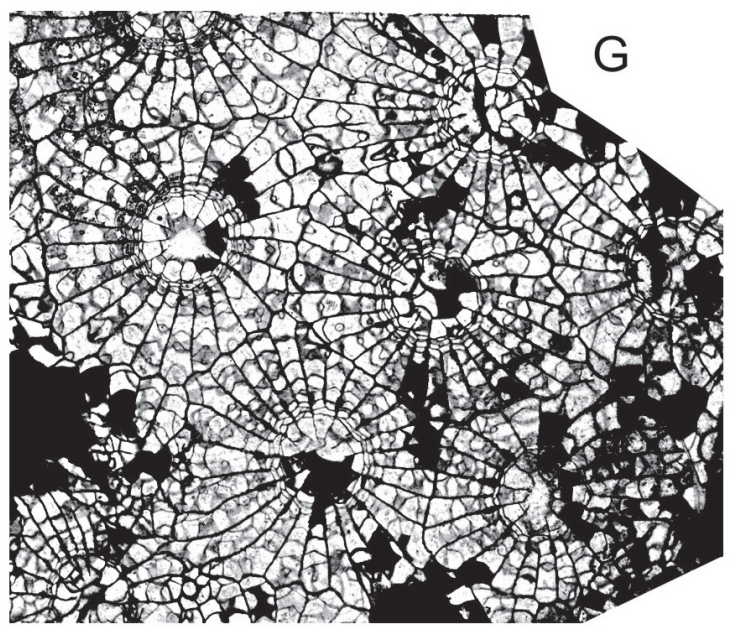

arom

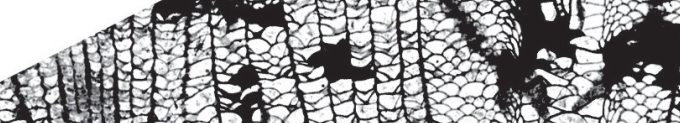
6 6.

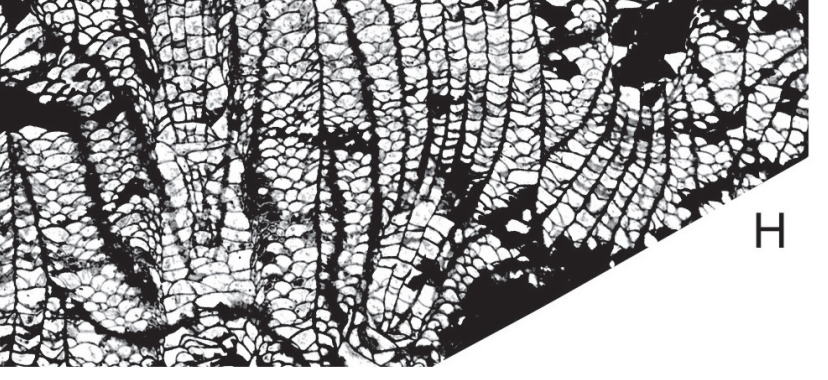

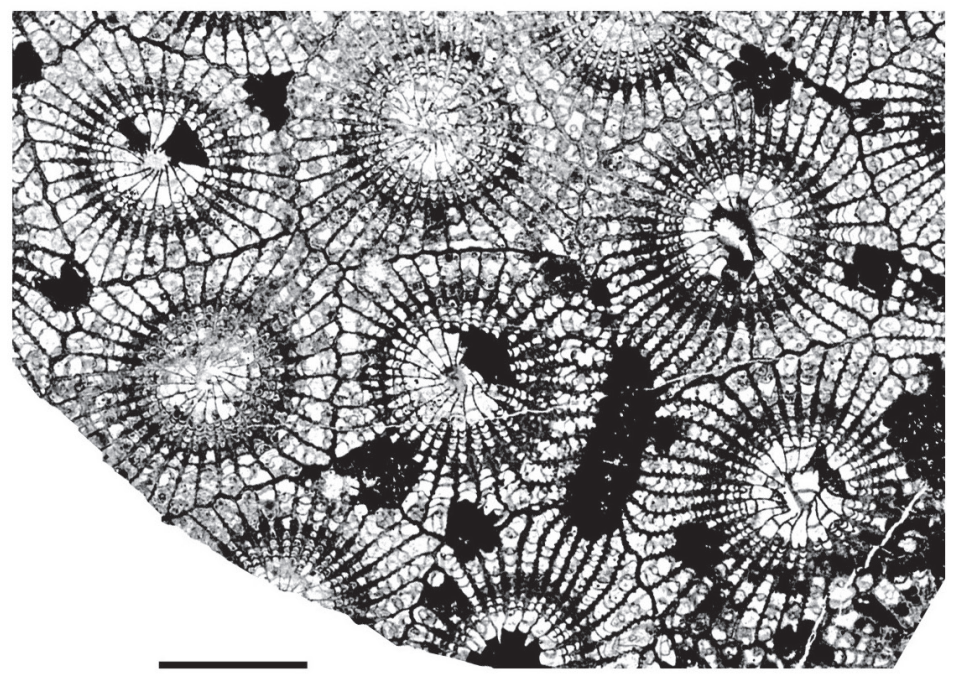

$$
0.5 \mathrm{~cm}
$$

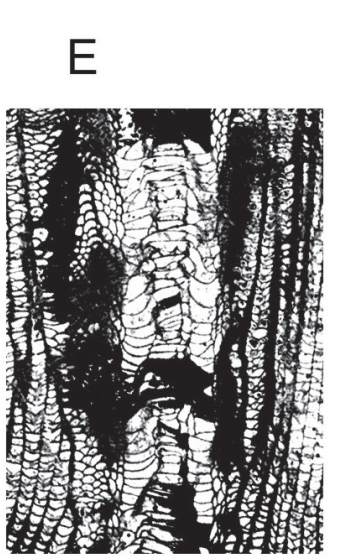

Plate 1. A-F: Potyphyllum ananas (Goldfuss, 1826). A-C: Neotype, IRScNB a12989, Couthuin MC-1980-2-X77 at Lavoir; transverse section and longitudinal sections. D-F: IRScNB a12990, Froidchapelle MC-75-D112 at Cerfontaine; transverse section and longitudinal sections. G-H: Potyphyllum veserense (Coen-Aubert, 1974). IRScNB a12993, Froidchapelle MC-71-C945 at Cerfontaine; transverse and longitudinal sections. Magnification x 3. 

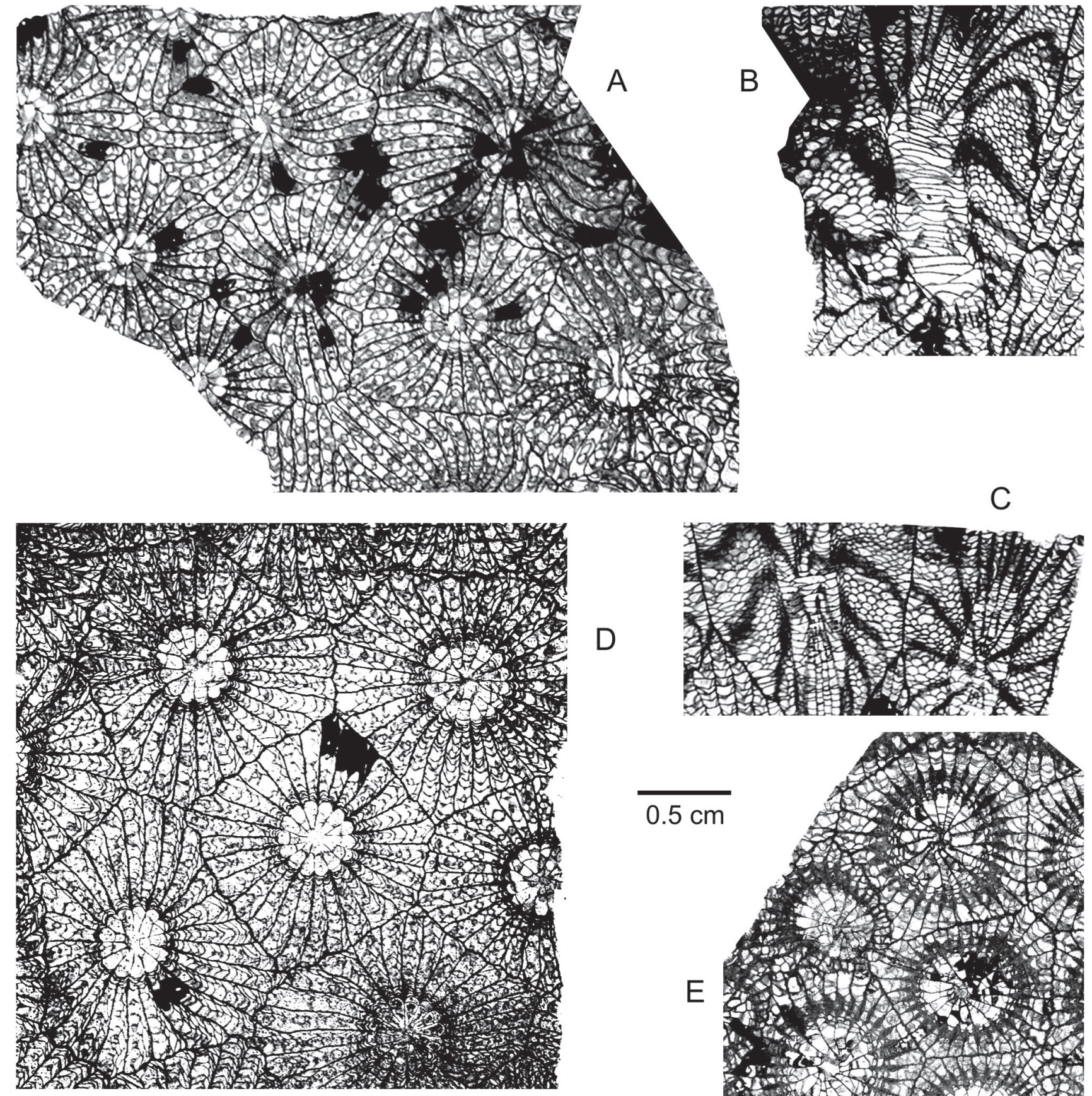

C
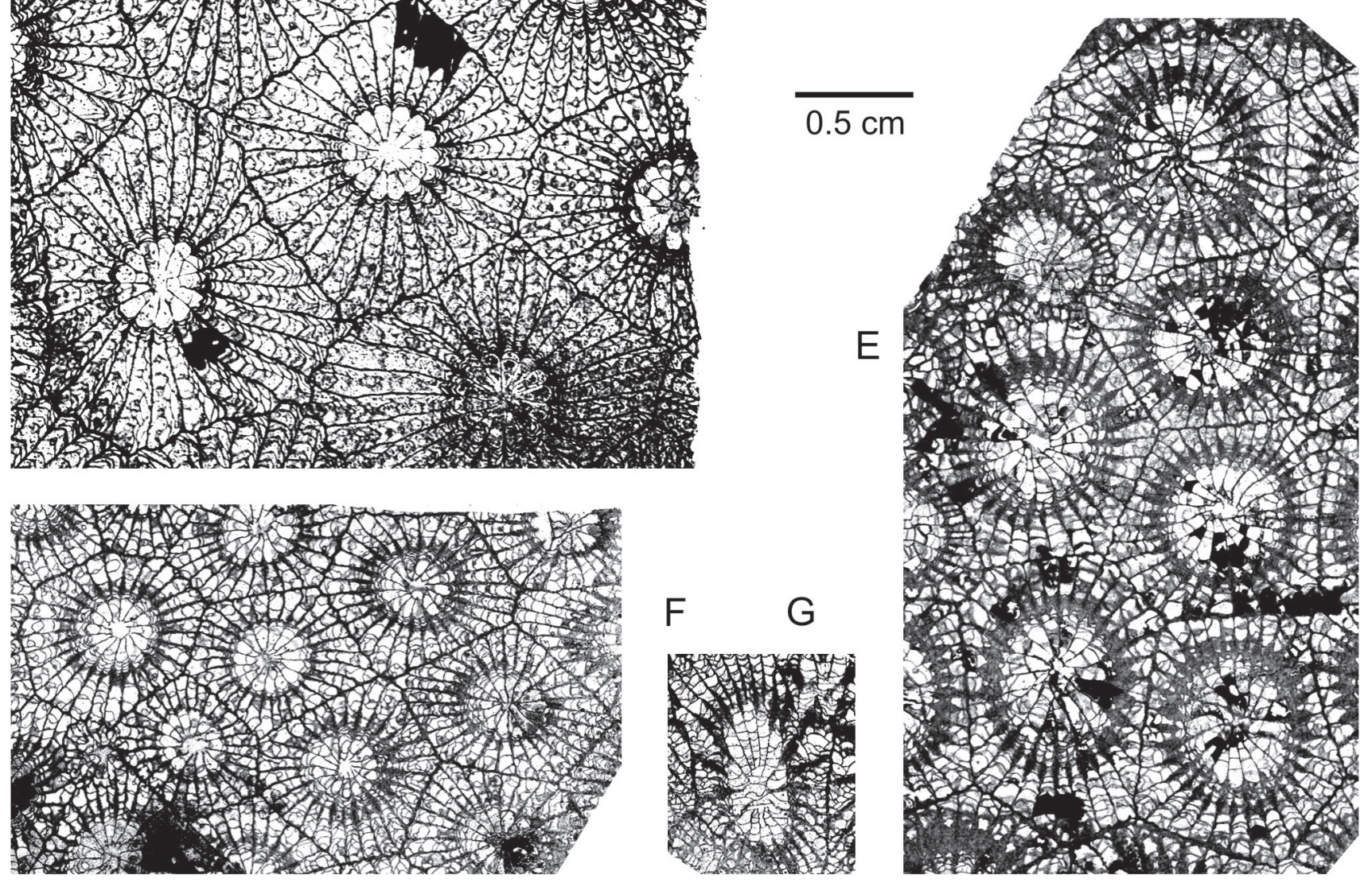

Plate 2. A-D: Potyphyllum veserense (Coen-Aubert, 1974). A-C: IRScNB a12994, Aye MC-114-D813 at Marche-en-Famenne; transverse section and longitudinal sections. D: IRScNB a12995, Aye MC-114-D816 at Marche-en-Famenne; transverse section. E-G: Potyphyllum ananas (Goldfuss, 1826). E: IRScNB a12991, Hamoir MC-120-D859 at Bomal; transverse section. F-G: IRScNB a12992, Senzeille MC-1984-1-T200 at Neuville; transverse and longitudinal sections. Magnification x 3. 